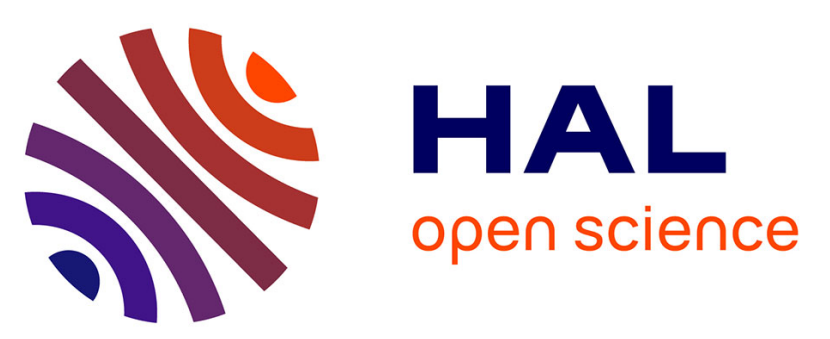

\title{
Direct and indirect impact of sewage sludge compost spreading on Quercus coccifera monoterpene emissions in a Mediterranean shrubland
}

Romain Olivier, Michael Staudt, Anne-Violette Lavoir, Elena Ormeño, Syed Hussain Rizvi, Virginie Baldy, Annabelle Rivoal, Stephane Greff, Caroline Lecareux, Catherine Fernandez

\section{To cite this version:}

Romain Olivier, Michael Staudt, Anne-Violette Lavoir, Elena Ormeño, Syed Hussain Rizvi, et al.. Direct and indirect impact of sewage sludge compost spreading on Quercus coccifera monoterpene emissions in a Mediterranean shrubland. Environmental Pollution, 2011, 159 (4), pp.963 - 969. 10.1016/j.envpol.2010.12.003 . hal-01764689

\section{HAL Id: hal-01764689 \\ https://hal-amu.archives-ouvertes.fr/hal-01764689}

Submitted on 12 Apr 2018

HAL is a multi-disciplinary open access archive for the deposit and dissemination of scientific research documents, whether they are published or not. The documents may come from teaching and research institutions in France or abroad, or from public or private research centers.
L'archive ouverte pluridisciplinaire HAL, est destinée au dépôt et à la diffusion de documents scientifiques de niveau recherche, publiés ou non, émanant des établissements d'enseignement et de recherche français ou étrangers, des laboratoires publics ou privés. 


\title{
Direct and indirect impact of sewage sludge compost spreading on Quercus coccifera monoterpene emissions in a Mediterranean shrubland
}

\author{
Romain Olivier ${ }^{\mathrm{a}}$, Michael Staudt ${ }^{\mathrm{b}}$, Anne-Violette Lavoir ${ }^{\mathrm{a}}$, Elena Ormeño ${ }^{\mathrm{a}}$, Syed Hussain Rizvi ${ }^{\mathrm{a}}$, \\ Virginie Baldy ${ }^{\mathrm{a}}$, Annabelle Rivoal ${ }^{\mathrm{a}}$, Stephane Greff ${ }^{\mathrm{a}}$, Caroline Lecareux ${ }^{\mathrm{a}}$, Catherine Fernandez ${ }^{\mathrm{a}, *}$ \\ a Aix-Marseille Université - Institut Méditerranéen d'Ecologie et de Paléoécologie (IMEP), UMR 6111, Equipe Diversité Fonctionnelle des Communautés \\ Végétales - Centre de St Charles, Case 4, 13331 Marseille Cedex 03, France \\ bépartement Fonctionnement des Ecosystèmes, Centre d'Ecologie Fonctionnelle et Evolutive (CEFE, UMR 5175), 1919 Route de Mende, 34293 Montpellier Cedex 5, France
}

Compost spreading in Mediterranean shrublands has no strong short-term effect on Q. coccifera monoterpene emissions at leaf level.

Keywords:

Monoterpenes

Biogenic emissions

Compost

Quercus coccifera

Nutrients

\begin{abstract}
A B S T R A C T
Monoterpene emissions of Quercus coccifera $\mathrm{L}$. were repeatedly measured during the two years following the spreading of a sewage sludge compost at rates of $50 \mathrm{Mg} \mathrm{ha}^{-1}$ and $100 \mathrm{Mg} \mathrm{ha}^{-1}$, in a twelve-year-old post-fire Mediterranean shrubland. We also monitored the patterns of change in soil and leaf nutrient content, plant water potential, chlorophyll fluorescence, and plant growth. Compost spreading resulted in weak changes in leaf nutrient content and plant water status, and therefore no significant effect on monoterpene emissions at leaf scale, except during one summer sampling, probably related to advanced leaf maturity with the highest compost rate. However, compost increased plant growth, particularly the leaf biomass. The results suggest that compost spreading in Mediterranean shrublands has no strong short-term effect on $Q$. coccifera monoterpene emissions at leaf level, but may indirectly increase volatile organic compound fluxes at the stand scale, which may contribute to regional ozone pollution.
\end{abstract}

\section{Introduction}

Almost 50\% of the plant species growing in Mediterranean type ecosystems produce and emit biogenic volatile organic compounds (BVOC) (Ross and Sombrero, 1991). Among these compounds, monoterpenes account for $11 \%$ of the global annual BVOC fluxes (Guenther et al., 1995). Terpene emissions are involved in atmospheric chemistry, notably by affecting the formation and degradation of tropospheric ozone in regions subjected to high solar radiation and in proximity to urban areas which are main sources of ozone precursors (Atkinson and Arey, 2003). These emissions are directly involved in air pollution (Varinou et al., 1999), particularly in the Mediterranean region, where critical ozone levels are recorded each year (European Environment Agency, 2009). BVOC emissions are also known to contribute to secondary organic aerosol formation (Guenther, 2002) and may increase the life span of greenhouse gases, such as $\mathrm{CH}_{4}$, which are strongly involved in global change processes (Guenther et al., 1995).

A wide range of environmental factor have been shown to affect BVOC emissions. While the effect of climate-related factors is well

\footnotetext{
* Corresponding author.

E-mail address: catherine.fernandez@univ-provence.fr (C. Fernandez).
}

documented, global eutrophication and soil nutrient impact on BVOC fluxes has received relatively little attention (Peñuelas and Staudt, 2010). For some years, studies have been carried out to assess the benefits and risks of using composted wastes to restore degraded natural soils, as an alternative to incinerating or dumping them (Gallardo-Lara and Nogales, 1987; Navas et al., 1999; Martinez et al., 2003; Larchevêque et al., 2006b, 2009). So far, the effects of compost on BVOC production have been investigated by a few studies which focused only on terpene content (Tanu et al., 2004; Hussein et al., 2006; Abdelaziz et al., 2007), but there have been none on emissions. The spreading of nutrient rich compost may directly affect the plant capacity to produce and emit BVOCs. Fertilization experiments have indeed been shown to increase or reduce foliar BVOC emissions depending on the type and dose of nutrients and experimental conditions (Harley et al., 1994; Lerdau et al., 1995; Litvak et al., 1996; Constable et al., 1999; Possell et al., 2004; Rosenstiel et al., 2004; Blanch et al., 2007; Fares et al., 2008).

In this context, our aim was to assess the effect of sewage sludge compost spreading, during two consecutive years, on the seasonal course of Quercus coccifera L. monoterpene emissions, in a natural Mediterranean shrubland. Q. coccifera is an interesting model species for the Mediterranean area since this evergreen shrub covers a large surface of calcareous shrublands and is a pioneer species in post-fire lands (Konstantinidis et al., 2005). Furthermore, 
little is known about its emission variability according to abiotic factors other than seasonality and drought. This species mainly features monoterpene emissions (Ormeño et al., 2007b) which are expected to behave in an "isoprene-like" way, since it does not have specialized structures to store terpenes (Hansen and Seufert, 1996; Niinemets et al., 2002).

\section{Material and methods}

\subsection{Experimental set-up}

The experiment took place on the plateau of Arbois (Southern Provence, France: $5818960 \mathrm{E}-438299100 \mathrm{~N}$ in WSG-84 Norm), an area of $6000 \mathrm{~m}^{2}, 240 \mathrm{~m}$ above sea level, under Mediterranean climatic conditions, with hot, dry summers and cool, wet winters. The soil is calcareous, classified as Rendoll (Soil Survey Staff, 1999), with a high percentage of stones (77\%). This confers a very heterogeneous structure and soil depth. It shows low organic matter and available nutrient content (Larchevêque et al., 2006a). The vegetation is that of a typical Mediterranean shrubland, composed of evergreen shrubs ( 30 to $100 \mathrm{~cm}$ high) such as Quercus coccifera L., Cistus albidus L., Rosmarinus officinalis L., and Ulex parviflorus Pourr. This shrubland underwent a fire in June 1995, from which these pioneer species developed to form the current stand.

The compost tested in this study was made from green wastes, pine barks and municipal sewage sludge in identical proportions. This mature compost met the French legal standards (NF U 44-095) for pathogenic microorganisms, organic trace elements and trace metals. The nutrient constitution of the compost was similar to that used in Larchevêque et al. (2009) (total N: $2 \%$ of dry matter (DM); total P: $3.2 \%$ DM; exchangeable K: $0.32 \% \mathrm{DM}$; $\mathrm{pH}\left(\mathrm{H}_{2} \mathrm{O}\right)$ : 7.7). It was homogeneously hand-spread in May 2007 on the soil of $10 \times 10 \mathrm{~m}$ randomly arranged plots. Three blocks received $50 \mathrm{tha}^{-1}$ (D50) and three others $100 \mathrm{t} \mathrm{ha}^{-1}$ (D100) (fresh mass). The later spreading dose corresponds to the maximum authorized by the French legislation. Three control plots were kept untreated. All plots were surrounded by natural untreated shrubland, demarcated only by plastic tape, and were only a few meters apart from each other.

Daily mean temperature, daily sum of precipitation and decadal global radiation were acquired from the Météo-France Galice station, located a few kilometers from the site $(5255000 \mathrm{E}-433180000 \mathrm{~N})$.

\subsection{Sampling and measuring protocol}

VOC sampling and plant material collection were repeatedly performed from summer 2007 to summer 2009 (2nd July, 30th November 2007, 29th February, 5th June, 23rd June, 10th September 2008, and 24th June 2009), taking care not to perform BVOC measurement or biological material collection on plants with developing leaves (growth flushes in April-May, sometimes also September-October depending on individuals and weather), as the phenological stage can strongly affect emission rates (Bertin et al., 1997). Each sampling campaign was carried out on three consecutive days.

Diurnal chlorophyll fluorescence measurements were done during the $15 \mathrm{~min}$ BVOC emission sampling, in late June 2008 and 2009.

Predawn xylem water potential measurements were performed from November 2007 to November 2008, on the first day of each BVOC sampling campaign and every two weeks between June and September 2008.

Twig collection for plant growth assessment was done in February 2010, thus integrating all 2009 growth. Samples were collected on ten individuals of each plot (thirty replicates per treatment).

Soil was collected around the BVOC sampling period, in July and November 2007, February, June and September 2008, and June 2009. One extra soil sampling was performed in November 2008

\subsection{Monoterpene emission sampling, analyses and normalization of emission data}

VOC sampling was carried out on sunny and windless days, randomizing the three treatments between $10 \mathrm{a} . \mathrm{m}$. and 14 p.m. (universal time). Emissions were sampled randomly on 3 to 6 individuals on each of the three plot replicates ( 9 to 18 replicates per treatment). No BVOC sampling was performed twice on the same individual since twig sampling removed a major part of the early-resprouted plant. To achieve representative emissions from $O$. coccifera individuals, twigs were selected with no attention to the number of annual growth flushes, which could vary from a plant to another. We used 3 to 6 dynamic head-space systems to simultaneously collect BVOC emissions from all replicates, on each plot. On each plant, a $10 \mathrm{~L}$ transparent oven bag $\left(\right.$ Nalophan $\left.^{\circledR}\right)$ was carefully placed around a small healthy and sun-exposed twig bearing mature leaves, without closing it, at least one hour before sampling. On average, the enclosed leaf dry mass was $4.6 \pm 2 \mathrm{~g}$. In each bag an inlet and outlet air port was connected to chemically inert Tygon ${ }^{\circledR}$ tubings. Inlet air was filtered, purified (Zero-air'TM Generator; Perma Pure LLC., New Jersey, USA) and directed into the bag at a flow rate of $400 \pm 50 \mathrm{~mL} \mathrm{~min}^{-1}$, measured with a digital mass flow controller (Aalborg ${ }^{\circledR}$ CFC17; 0-500 mL). A 30 min air-renewing period was performed before sampling to minimize possible stress experienced by the leaves during bag installation. This pre-purging allowed the bag atmosphere to be renewed at least once completely. Afterwards, BVOCs were sampled during $15 \mathrm{~min}$ by passing a fraction of the bag air at $100 \pm 20 \mathrm{~mL} \mathrm{~min}^{-1}$ through an adsorbant glass cartridge, by means of a void pump (Edwards RV8) and a bubble flowmeter (GPE, 'MeTeRate' 314-140/084 tube; Precision Engineering Ltd., Hemel Hempstead, UK). The adsorbant cartridge was filled with preconditioned Tenax TA (Varian ${ }^{\circledR}$ ) and protected from sun-light with aluminum foil. During sampling, the bag remained over-pressurized, thus limiting contact between the leaves and the bag's inner surface. Inside the bag, temperature was measured near the leaves, while a small fan homogenized the atmosphere. Temperature within the bags - known to represent leaf temperature quite faithfully (Ortega and Helmig, 2008) - was generally $2 \pm 1{ }^{\circ} \mathrm{C}$ higher than outside temperature. Photosynthetic photon flux density (PPFD) was measured outside bag enclosures using a portable photosystem plant and canopy transmission meter (EMS-7 Model; Surechem ${ }^{\circledR}$ Marketing SDN, BHD, Kuala Lumpur, Malaysia). Preliminary tests showed that PPFD inside the bag over the upper leaves was not different from values recorded outside. After BVOC sampling, cartridges were protected and frozen using liquid nitrogen, then stored at $-20^{\circ} \mathrm{C}$ in the laboratory until analysis. Emissions were expressed on a leaf dry mass basis, determined after lyophilization of the sampled twigs.

Terpene analyses were conducted by gas chromatography (Pengcheng et al., 2008) coupled with a flame ionization detector (HP 5890 series II, Agilent, Palo Alto, CA, USA) equipped with a non-polar chromatographic column (Ultra 2, $50 \mathrm{~m} \times 0.2 \mathrm{~mm} \times 0.25 \mu \mathrm{m}$ ). Tenax TA cartridges were previously back-flushed during $3 \mathrm{~min}$ at $60^{\circ} \mathrm{C}$ to eliminate trapped water. Preliminary tests showed no significant compound loss during this pre-flush. Trapped monoterpenes were then desorbed at $250{ }^{\circ} \mathrm{C}$ for $10 \mathrm{~min}$. After injection, temperature was set to $40^{\circ} \mathrm{C}$, then increased by $3{ }^{\circ} \mathrm{C}$ per minute to $250^{\circ} \mathrm{C}$ maintained for $5 \mathrm{~min}$. Carrier gas flow $\left(\mathrm{N}_{2}\right)$ was $1 \mathrm{~mL} \mathrm{~min}^{-1}$. Calibration was done with internal standard (dodecane) in each analysis, together with the frequent injection of commercial terpene standards (Sigma-Aldrich ${ }^{\circledR}$. Firmenich ${ }^{\circledR}$ ). Peak identification was done using retention indexes (Adams, 1989) and comparison with standard retention times, and was confirmed by analyzing some samples in a GC (Hewlett Packard GC6890 ${ }^{\circledR}$, Agilent, Palo Alto, CA, USA) coupled to a mass selective detector (MSD, HP 5973N).

Because $Q$. coccifera is a BVOC emitting species which does not store monoterpene, its field emission rates can be normalized to standard temperature $\left(30^{\circ} \mathrm{C}\right)$ and PPFD $\left(1000 \mu \mathrm{mol}\right.$ photons $\left.\mathrm{m}^{-2} \mathrm{~s}^{-1}\right)$ values using Guenther et al. (1993) for isoprene emissions. This algorithm allows a correction of emission rate embodying short-term effects of temperature and light:

\section{$E_{\mathrm{s}}=\frac{E}{C_{\mathrm{L}} \times C_{\mathrm{T}}}$}

where $C_{\mathrm{L}}$ and $C_{\mathrm{T}}$ are respectively light and temperature dependence coefficients derived from experimental measurements on several isoprene emitting species. Parameters used to calculate these coefficients are those proposed in Guenther et al. (1993). Hereafter, normalized and un-normalized emission rates are referred to as $E_{\mathrm{s}}$, and $E$ respectively.

\subsection{Leaf and soil sampling and nutrient analyses}

After BVOC sampling, leaves of each twig were cut off, lyophilized (Alpha 1-4 LD plus, Christ $\mathrm{GmbH}$, Germany), and reduced to powder with a ball mill.

Soil samples were taken a few $\mathrm{cm}$ under the litter-compost layer, taking care not to include compost fragments. Each sample was a mixture of three soil collections randomly performed on each plot. The soil was oven-dried at $60^{\circ} \mathrm{C}$ for $48 \mathrm{~h}$, sieved and ground in a ball mill.

Leaf and soil N content were analyzed with a Flash EA 1112 Elemental Analyzer (Thermo Finnigan, Milan, Italy). Leaf $\mathrm{P}$ and $\mathrm{K}$ contents as well as soil available $\mathrm{P}$ (Olsen method) and extractable $\mathrm{K}$ content were analyzed in the LCA (Laboratoire Centre Atlantique, La Rochelle, France) with an ICP (inductively coupled plasma) method.

\subsection{Fluorescence measurement and xylem water potential}

Diurnal chlorophyll fluorescence measurements were performed on the plants chosen for BVOC sampling, using leaves nearby those enclosed. For each individual, the fluorescence of three sun exposed leaves was measured, using a portable Fluorescence Monitoring System (FMS 2, Hansatech ${ }^{\circledR}$, Kings Lynn, Norfolk, UK). Each measurement provided a variable to maximum fluorescence ratio ( $\mathrm{Fv} / \mathrm{Fm}$ ) value after 30 min dark-adaptation with a leaf clip holder. Fv/Fm is a measure of the quantum efficiency when all Photosystem II (PSII) centers are open, i.e., the maximum yield of light energy conversion, in a given environmental situation (Krause and Weis, 1991).

Predawn xylem water potential measurements were done using a pressure chamber (PMS Instrument Co. Corvallis, Oregon. USA) connected to a nitrogen tank Measurements were performed on other individuals than those used for BVOC sampling to prevent any injury effect on the emissions rates. Three to five twigs were 
withdrawn (each twig representing a different plant) in each plot, corresponding to 9 to 15 measurements per treatment.

\subsection{Growth measurement}

As Kermes Oak makes one (exceptionally two) flush per year, depending on the climatic conditions (Pilar and Gabriel, 1998), growth measurements were performed on the three growth units of the longest axis, so that measurements integrate all the 2009 and at least part of the 2008 growth. We measured wood dry weight and dimensions on each of these growth units. Approximate wood volume was assessed by multiplying the basal diameter of the stem by its length. We counted the number of ramifications corresponding to the last flush (on the $n-1$ growth unit). On the last main growth unit (n) of the twig, we determined the number of leaves, measured their dry weight and calculated their Leaf Mass per Area ratio (LMA)

\subsection{Statistical analyses}

Repeated-measurements analyses (within subject ANOVA; von Ende, 2001) were performed with Statistica Edition 98 (StatSoft Inc., Tulsa, OK, USA) when comparing variables between non-independent individuals such as individuals from the same plots at different dates. It was used to test the effect of compost on $E$ and $E_{S}$, and on leaf nutrient content. One-way ANOVA was performed using Statistical Graphics Plus 4.1 (Statpoint Onc, North Virginia, USA) to test the effect of compost on growth variables. Postulates for normality of distribution within each group as well as homoscedaticity (variance homogeneity) were checked before ANOVAs, and data were transformed where needed to correct deviations from normality. When the data did not meet these requirements, as for soil nutrient, fluorescence and water potential, Kruskal-Wallis test was rather used, on Statistical Graphics Plus 4.1. Post hoc multiple range comparisons were done using Tukey test after ANOVA and Student-Newman-Keuls non-parametric tests after Kruskal-Wallis test.

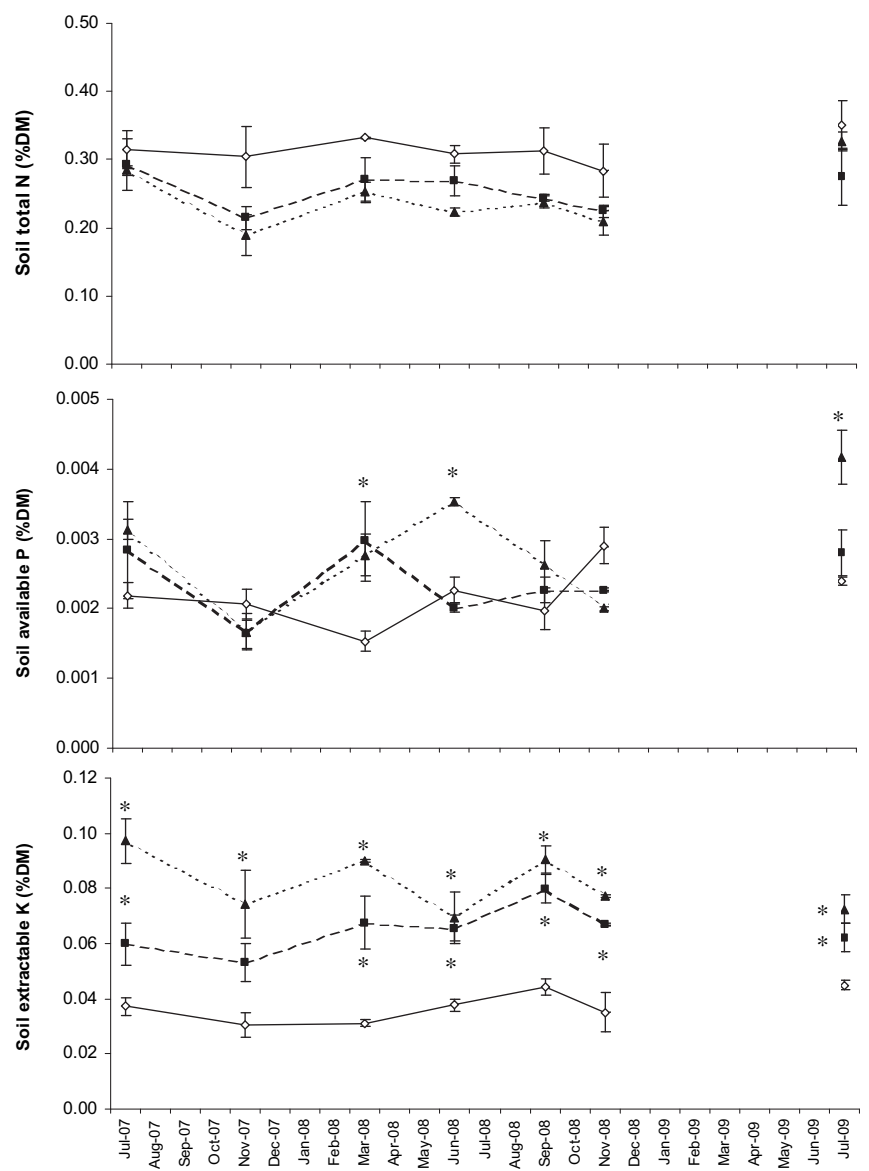

Fig. 1. Soil total nitrogen, available phosphorus and extractable potassium conten through dates and treatments as a percentage of dry matter (DM). ( $\diamond:$ control, D50, $\boldsymbol{\Delta}$ : D100). Error bars represent standard error $(n=3) .^{*}$ Denotes a significant difference from the control mean $(P<0.05)$ (Kruskal-Wallis test).

\section{Results}

\subsection{Soil and foliar nutrients}

Mineral soil total nitrogen was not significantly altered by compost treatments (Kruskal-Wallis tests, $W=4.4, P>0.05$; Fig. 1). Available phosphorus increased sporadically in March, June 2008 and July 2009. Most of the significant changes in mineral soil nutrients were observed on extractable $\mathrm{K}$ content which was quickly and durably enhanced by compost spreading.

Consistently with soil nutrient content, leaf nutrient content was poorly affected by the compost spreading (Fig. 2). No compost effect was observed on leaf $N$ content throughout the survey period (Within subject ANOVA; $F=1.6, P>0.05$ ). Similarly to soil $P$, leaf $P$ was affected only sporadically by the compost treatments. Leaf $\mathrm{K}$ was increased by both compost doses but only for the sampling done two years after spreading (July 2009). For both soil and leaf nutrient content, we observed relatively few differences between the two compost doses.
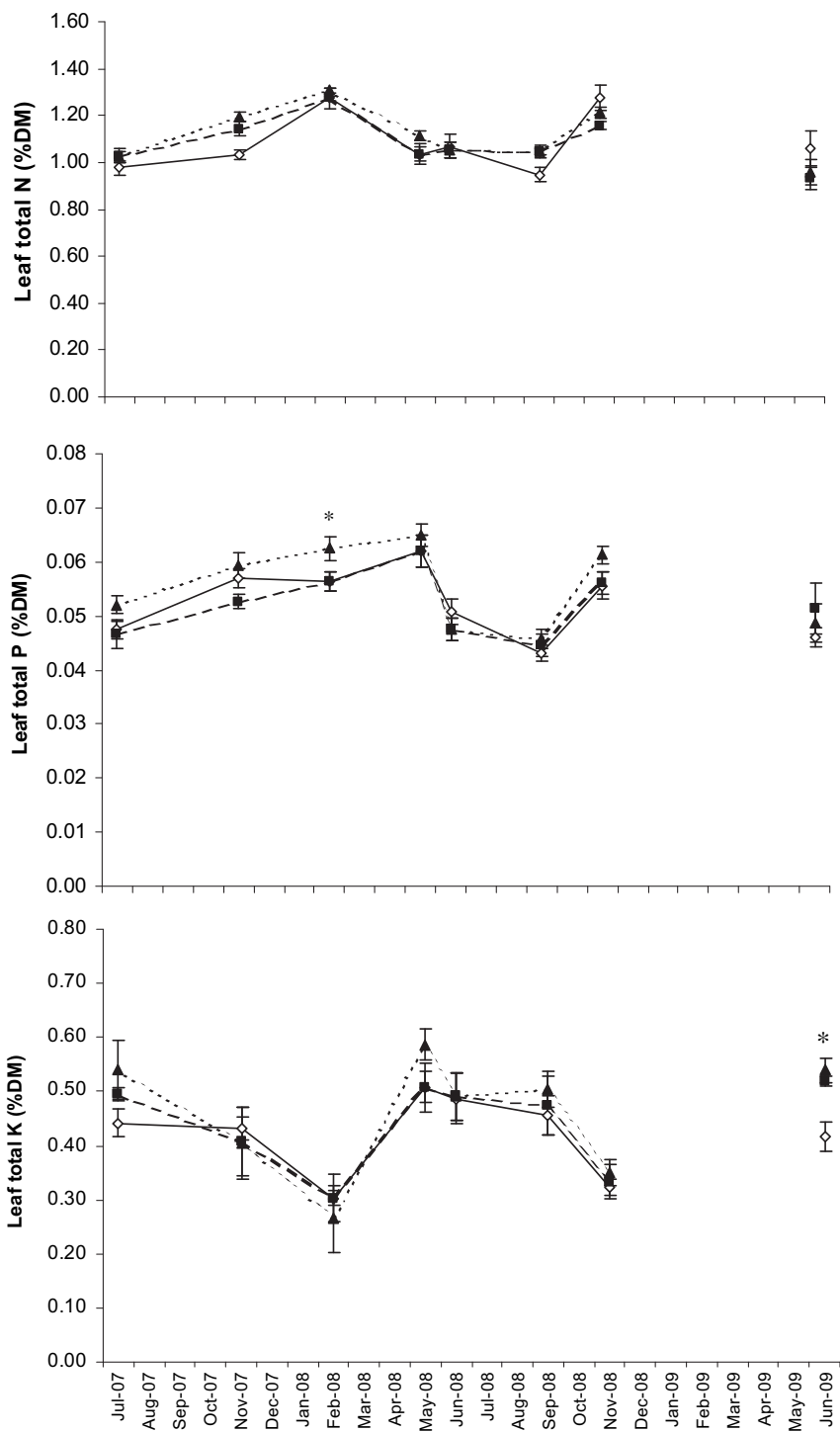

Fig. 2. Leaf total nitrogen, phosphorus and potassium content through dates and treatments as percentage of dry mass ( $\diamond$ : control, $\mathbf{\square}$ : D50, $\mathbf{\Delta}:$ D100). Error bars represent standard error $(n=3)$. Asterisks denote a significant difference from the control mean $(*: P<0.05)$ (Within subject ANOVA). 


\subsection{Growth}

Despite the low enrichment of the mineral horizon in $\mathrm{N}$ and $\mathrm{P}$, the compost spreading improved vegetation growth (Table 1). Compost spreading did not affect either LMA or the number of leaves on the last main growth unit, but increased total leaf dry weight by more than $40 \%$ in D50 and D100, resulting in larger leaves. D100 treatment raised by $87 \%$ the mean number of ramifications on the $n-1$ growth unit. The diameter of the stems and their length was significantly increased in D100 in all growth units, leading to a total axial wood volume raised by $130 \%$ in D100.

\subsection{Plant water status and leaf fluorescence}

Climate data showed high summer irradiance levels and typical Mediterranean patterns of precipitation, with summer drought leading to xylem water potential reduction (Kruskal-Wallis tests, $W=60, P<0.001$; Fig. 3, A) and B)). At week scale, mean summer temperature variations were sawtooth-shaped, given that increases or decreases of several degrees in a few days occurred frequently.

Predawn water potential monitoring showed that no BVOC sampling was done during the strongest water deficit period, in 2008. Early and late summer samplings were performed on plants with water potentials above $-1.5 \mathrm{MPa}$. Compost supply had no significant effect on plant water status during drought periods (Fig. 3, B)); $W=1.38, P>0.05$ ).

In 2008 and 2009, daytime fluorescence measurements showed $\mathrm{Fv} / \mathrm{Fm}$ values lower than 0.80 (Table 2). However, Fv/Fm tended to be higher in the compost treated plots than in the control plots and this difference was significant in early June 2008 (Kruskal-Wallis tests; $W=6.2, P<0.05)$.

\subsection{Monoterpene emissions}

Mean total E varied widely with seasons, with the lowest values around $1 \mu \mathrm{g} \mathrm{gDM}^{-1} \mathrm{~h}^{-1}$ from late November to early June, and values more than four times higher in summer (4.1 to $9.4 \mu \mathrm{g}$ $\mathrm{gDM}^{-1} \mathrm{~h}^{-1}$ )(Fig. 3, C)). No compost effect on E was evidenced. Mean total $E_{\mathrm{s}}$ varied between 1.3 and $9.6 \mu \mathrm{g} \mathrm{gDM}^{-1} \mathrm{~h}^{-1}$ through dates and treatments (Fig. 3, D)). No correlation was found between $E_{\mathrm{s}}$ and leaf nutrient content (data not shown). In June 2008, when the two different sampling dates were only two weeks apart, we still observed a strong increase in the total $E_{\mathrm{S}}$ (on average 3.6 times up), similar in each treatment. Late June/early July $E_{\mathrm{s}}$ were not significantly different from one year to another. Normalization enhanced 7 to 10 times emissions in November and overall increased data variances within treatments in November and February samplings. Compost spreading did not affect $E_{\mathrm{s}}$ throughout the survey period, except in early June 2008 where $E_{\mathrm{s}}$ was significantly enhanced by 2.5 in the D100 treatment (Fig. 3, D)).

The main emitted compound, throughout the experimental period, was $\alpha$-pinene (34\%), followed by limonene (25\%) and $\beta$ myrcene (16\%), whereas $\beta$-pinene, 1,8-cineol, sabinene, camphene, $\alpha$-terpineol and $\gamma$-terpinene contributed less than $6 \%$ to the total emissions. A sesquiterpene ( $\alpha$-humulene) was identified but detected in negligible proportions $(<1 \%)$, so it was not included in the data analysis.

\section{Discussion}

\subsection{Seasonal emission variations and normalization effect}

Q. coccifera monoterpene E varied throughout seasons overall following seasonal temperature variations, with higher emissions during the warm period than during colder periods, as commonly described (Boissard et al., 2001; Sabillon and Cremades, 2001; Staudt et al., 2002; Pio et al., 2005). $E_{\mathrm{s}}$ values ranged within the same order of magnitude as that previously found for this species (Llusià and Peñuelas, 2000; Ormeño et al., 2007a). After normalization, the two close June 2008 samplings still revealed a sharp rise of $E_{\mathrm{s}}$ with values multiplied by 3 within two weeks. This increase was probably due to the exceptionally rapid weather change, with an $8{ }^{\circ} \mathrm{C}$ difference between the mean temperature of the first and the last ten day period in June. This suggests that mid term past weather (in the order of days), mainly mid term temperature, which is not integrated by the G93 normalization, could be one of the main environmental variables involved in this rapid summer increase (Fuentes and Wang, 1999; Sharkey et al., 1999).

The sporadic seasonal increases recorded here corroborate the results of Llusià and Peñuelas (2000) for the same species under field conditions, with higher $E_{\mathrm{s}}$ in summer and autumn than during the rest of the year. In their survey, four monoterpene emitting plant species were sampled, including Quercus ilex, the most commonly studied Mediterranean oak species, which is, like

Table 1

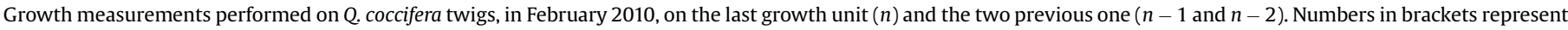
standard deviation $(n=30)$. Different letters denote significant differences between treatments (One way ANOVA). ns: non-significant.

\begin{tabular}{|c|c|c|c|c|c|c|c|}
\hline \multirow[t]{2}{*}{ Growth flush } & & \multirow[t]{2}{*}{ Control } & \multirow[t]{2}{*}{ D50 } & \multirow[t]{2}{*}{ D100 } & \multicolumn{3}{|c|}{ Post hoc Tukey test } \\
\hline & & & & & Control & D50 & D100 \\
\hline \multirow[t]{6}{*}{$n$} & $\varnothing(\mathrm{mm})$ & $2.05(0.6)$ & $2.66(0.6)$ & $2.65(0.7)$ & $\bar{a}$ & $\mathrm{~b}$ & $\mathrm{~b}$ \\
\hline & Length $(\mathrm{cm})$ & $5.62(2.7)$ & $6.12(2.4)$ & $7.97(3.1)$ & a & $\mathrm{a}$ & $\mathrm{b}$ \\
\hline & Number of leaves & $8.3(2.7)$ & $10.07(2.9)$ & $9.67(2.9)$ & ns & & \\
\hline & Leaf dry mass (g) & $0.16(0.08)$ & $0.25(0.15)$ & $0.23(0.15)$ & $a b$ & $\mathrm{c}$ & bc \\
\hline & Stem dry mass (g) & $0.12(0.09)$ & $0.19(0.15)$ & $0.22(0.15)$ & ns & & \\
\hline & LMA $\left(\mathrm{mg} \mathrm{cm}^{-2}\right)$ & $94(7.18)$ & $95(9.80)$ & $93(4.93)$ & ns & & \\
\hline \multirow[t]{4}{*}{$n-1$} & Number of ramifications & $3.67(2.34)$ & $5.17(3.05)$ & $6.87(3.01)$ & a & $\mathrm{ab}$ & $\mathrm{b}$ \\
\hline & $\varnothing(\mathrm{mm})$ & $2.78(0.73)$ & $3.45(0.70)$ & $3.68(0.93)$ & $\mathrm{a}$ & $\mathrm{b}$ & $\mathrm{b}$ \\
\hline & Length $(\mathrm{cm})$ & $4.19(2.4)$ & $5.53(3.0)$ & $6.87(3.1)$ & $a b$ & bc & $\mathrm{c}$ \\
\hline & Leaf dry mass ( $\mathrm{g}$ ) & $0.21(0.22)$ & $0.35(0.25)$ & $0.56(0.44)$ & $\mathrm{a}$ & $\mathrm{ab}$ & $\mathrm{b}$ \\
\hline \multirow[t]{3}{*}{$n-2$} & $\varnothing(\mathrm{mm})$ & $3.59(0.96)$ & $4.11(0.89)$ & $4.43(1.14)$ & $\mathrm{ab}$ & bc & c \\
\hline & Length $(\mathrm{cm})$ & $3.84(2.7)$ & $4.59(2.8)$ & $5.34(3.9)$ & $\mathrm{ab}$ & $\mathrm{ab}$ & $\mathrm{b}$ \\
\hline & Stem dry mass (g) & $0.39(0.48)$ & $0.54(0.4)$ & $0.76(0.89)$ & $\mathrm{ab}$ & $\mathrm{ab}$ & $\mathrm{b}$ \\
\hline \multirow[t]{3}{*}{ Sum } & Total length $(\mathrm{cm})$ & $13.65(6.42)$ & $16.24(5.81)$ & $20.18(8.2)$ & $a b$ & bc & $\mathrm{c}$ \\
\hline & Total stem dry mass (g) & $0.72(0.68)$ & $1.08(0.63)$ & $1.54(1.38)$ & $\mathrm{a}$ & $\mathrm{ab}$ & $\mathrm{b}$ \\
\hline & Total stem volume $\left(\mathrm{cm}^{3}\right)$ & $1.10(1.2)$ & $1.69(1.1)$ & $2.57(2.6)$ & $\mathrm{a}$ & $\mathrm{ab}$ & $\mathrm{b}$ \\
\hline
\end{tabular}



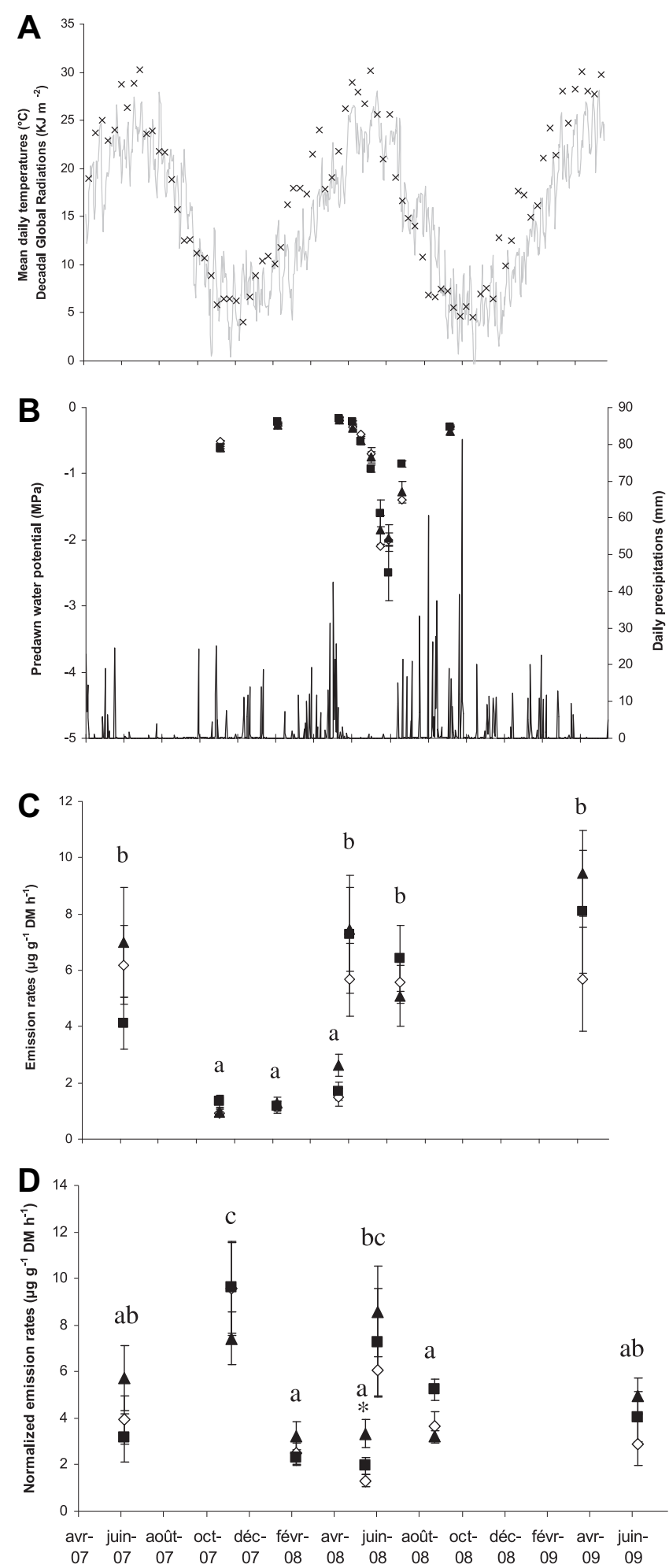

Fig. 3. Climatic conditions and emissions through season and compost treatments. A) $\times$ : daily temperature, grey line: decadal global radiation. B) black line: daily precipitations; symbols: predawn water potential ( $\diamond$ : control, $\mathbf{\square}:$ D50, $\mathbf{\Delta}:$ D100). Error bars represent standard error $(n=9$ to 15$)$. C) Total emission rates (Total E; sum of 9 monoterpenes). Error bars represent standard error ( $n=9$ to 18). Different letters denote significant differences between sampling dates (Within subject ANOVA; $F=33$, $P<0.001)$. Asterisks stand for compost treatments significantly different from control $(P<0.05)$. D) Total normalized emission rates (Total $\left.E_{\mathrm{s}}\right)$. Error bars represent standard error ( $n=9$ to 18). Different letters denote significant differences between sampling dates (Within subject ANOVA; $F=14, P<0.001$ ). Asterisks stand for compost treatments significantly different from control $(F=3.92, P<0.05)$.
Kermes Oak, a non-storing monoterpene emitter. Interestingly, they observed that Kermes Oak was the only species displaying delayed seasonal emission tendencies while $Q$. ilex rather showed the highest emissions rates in spring and the lowest in autumn. The increase in emission rate we observed in autumn may be related to some phenological events such as second growth flushes occurring with the first rain episodes in late summer. Fischbach et al. (2002) showed that monoterpene-synthase activity was 67\% higher in newly developed leaves of $Q$. ilex than in one-year-old leaves. Hence, June and November could correspond to periods of strong emissions due to a higher monoterpene synthase activity in recently-developed leaves.

The high $E_{\mathrm{s}}$ observed in autumn may also be due to the high uncertainty of the G93 algorithm under low temperatures (Simon et al., 2001). Indeed, normalization increased the emission variability among replicates measured in the cold season, while it decreased the emission variability in the warm season. Boissard et al. (2001) evaluated the accuracy of the G93 model on isoprene emissions from Ulex europaeus through the seasons and revealed an overestimation of $E_{\mathrm{s}}$ in the cool periods from early November to late January. The normalization with G93 is more accurate when light and temperature are close to the standard conditions $\left(30^{\circ} \mathrm{C}\right.$ and $1000 \mu \mathrm{mol} \mathrm{m}^{-2} \mathrm{~s}^{-1}$ ). The rise in emission rate we observed in November after normalization was also noticed by Sabillon and Cremades (2001) on Q. ilex, while the initial field emission rate they measured was relatively stable throughout the cold season.

\subsection{Compost effect on soil and leaf nutrients}

Due to its strong nutritive properties, compost was expected to improve soil fertility in the spread plots. However, only mitigated changes in soil nutrient content were observed, two years after spreading (n.b., on the same experimental site, $\mathrm{N}$ and $\mathrm{P}$ soil content were found to have durably increased only from 7 years after spreading; Olivier et al., in prep.). Consistently with Larchevêque et al. (2006a), we did not observe any increase in soil $\mathrm{N}$ content during the two years following soil amendment and therefore no enhancement in leaf $\mathrm{N}$ content. The compost used was a mix of sewage sludge and other organic wastes with high $\mathrm{C} / \mathrm{N}$ ratios (such as green wastes) which generally reduce the rate of nitrogen mineralization and provide slow release to the plants (Epstein et al., 1978). Besides, Kermes Oak has a relatively deep root system (Baquedano and Castillo, 2007) and we did not observe any fine root development in the surface compost layer. Therefore, nutrients had to percolate to deep mineral soil layers to be available for plants. Only sporadic enrichments in available phosphorus were found within the soil profile, probably resulting from rainy episodes favoring its leaching. In contrast to nitrogen and phosphorus, potassium percolation was much quicker and enabled a durable enrichment of the mineral soil layer, but led to enhancement of the leaf potassium content from June 2009 only.

\subsection{Compost did not have direct effect on monoterpene emissions}

Compost supply is generally expected to induce changes in soil nutritive and water status (Gallardo-Lara and Nogales, 1987; Martinez et al., 2003). Various fertilization effects on BVOC emissions have been described in the literature (Litvak et al., 1996; Possell et al., 2004; Blanch et al., 2007; Fares et al., 2008), but all of them are related to alterations in leaf nutrient concentrations. In the time frame of our study, going up to two years after spreading, little change in leaf nutrient concentrations was induced by the compost, which explains why no clear alteration of the foliar BVOC emissions was observed. 
Table 2

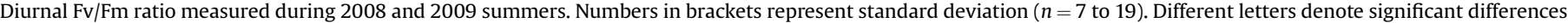
between treatments (Kruskal-Wallis test). ns: non-significant.

\begin{tabular}{|c|c|c|c|c|c|}
\hline & Measurement date & Control & D50 & D100 & Post-hoc SNK tests \\
\hline \multirow[t]{3}{*}{ Diurnal Fv/Fm } & 5 June 2008 & $0.764(0.025)^{\mathrm{a}}$ & $0.775(0.039)^{\mathrm{ab}}$ & $0.791(0.021)^{b}$ & $P<0.05$ \\
\hline & 23 June 2008 & $0.794(0.021)$ & $0.794(0.019)$ & $0.808(0.019)$ & ns \\
\hline & 24 June 2009 & $0.760(0.053)$ & $0.785(0.028)$ & $0.774(0.041)$ & ns \\
\hline
\end{tabular}

a Post-hoc Student-Newman-Keuls non-parametric tests.

In the Mediterranean region, summers are often stressful periods for plants due to high temperature and irradiance levels, and strong water deficit. Low water availability is known to negatively affect monoterpene emissions from $Q$. ilex if drought is very severe (Staudt et al., 2002; Lavoir et al., 2009). In our case, predawn xylem water potential remained clearly above $-2 \mathrm{Mpa}$, considered as a critical threshold (Lavoir et al., 2009) for BVOC emissions from $Q$. ilex under natural conditions. Compost did not induce any visible change in the plant's summer water status $(P>0.05)$, as observed by Larchevêque et al. (2009) at the same study site, one year after spreading. Mineral soil probably benefited from enhanced water retention in the first centimeters only, while deep soil layers penetrated by Kermes Oak root system may have remained unaffected by the compost spreading. Indeed, even though compost probably limited soil water evaporation, water uptake by long-root species such as Kermes Oak depends more on precipitation and water stored at depth than on surface water evaporation (Baquedano and Castillo, 2007). Consequently, the positive effect of compost on soil water retention was probably too weak to induce clear changes in BVOC emissions.

The increase of $E_{\mathrm{s}}$ with compost observed in early June 2008 was probably related to better photosynthetic performance. Indeed, in early June 2008, the increase of Fv/Fm with compost was significant and comparable to that of monoterpene emissions. Emissions of monoterpenes from non-storing species were shown to be correlated with photosynthetic parameters (Niinemets et al., 2002). Compost may have induced earlier leaf development in April-May, resulting in a higher photochemical efficiency at the beginning of June 2008, while leaves from control treatments could have been mature but not yet fully photosynthetically active. Even if the whole photosynthetic machinery is already present in the leaf, it may take several weeks before this leaf reaches its maximum photosynthetic capacity (Both and Brüggemann, 2009).

On the other hand, potassium, the only element significantly supplied by the compost so far, could also explain the Fv/Fm and $E_{\mathrm{s}}$ increase in early June 2008. Potassium is known to have essential functions in osmotic regulation but also favorable effects on $\mathrm{CO}_{2}$ assimilation (Mengel and Kirkby, 2001). Moreover, it was shown to enhance protection against high solar irradiance levels and increase plant resistance to drought (Ismail, 2005), both conditions being typical of summers under Mediterranean climate.

\subsection{Indirect effects of compost spreading on monoterpene emissions}

Although compost did not affect leaf nutrient content, it enhanced plant growth in most of the investigated variables. This biomass increase could also explain why leaf nutrients were not much enriched in the treated plots. The higher nutrient pools available to the plants were probably used in higher biomass production (Chapin, 1980). Over two years, compost increased the wood biomass, thus allocating nutrients to non-emitting organs which were not investigated in this study. Moreover, spreading enhanced the number of ramifications and the leaf dry mass, resulting in larger leaves, since LMA was not affected. As a consequence, at plot scale, the first effect of compost on Kermes Oak BVOC emissions appeared indirectly through this annual increase of emitting biomass. This indirect effect has to be taken into account since its impact on regional-scale emissions is independent of climatic conditions and constant all the year long.

\section{Conclusion}

Emissions of monoterpene from $Q$. coccifera were assessed in a Mediterranean shrubland after compost spreading. Variable normalized emission rate was observed, depending on the season, with higher rates in the heart of summer and in autumn than during the rest of the year. Our data showed that emission normalization with Guenther's algorithm does not always reduce measure variability, notably in autumn and winter, seasons for which the model seemed to be inappropriate.

Two years after spreading, compost did not directly affect BVOC emissions at leaf scale, but indirectly enhanced annual emissions by increasing emitting leaf biomass. Further measurement on the experimental site will allow assessment of the longer-term effect of this amendment, and the expected plant nutrition enhancement with the advanced mineralization of the compost.

Even if compost spreading in natural lands can be an interesting recycling outlet for sewage sludge production, the impact of this practice on BVOC emitting species has to be considered since it indirectly contributes to regional scale ozone pollution. Biogenic emissions are now recognized as one of the major sources of tropospheric ozone. This is particularly relevant in the Mediterranean region which is, each summer, one of the European zones most exposed to ozone pollution. In this season and at this location, several of the factors contributing to ozone accumulation are combined: BVOC emitting species, high temperatures increasing emissions, high irradiance levels contributing to ozone formation by allowing atmospheric photochemical reactions, and high vehicle traffic - in a region that is a frequent holiday destination - leading to enhanced production of ozone precursors.

\section{Acknowledgments}

We thank Capucine Massot, Sylvie Dupouyet, Fabien Arene, Muhammad Sohail, Diane Cattenoz, Sylvain Bernardand and Phyltre for field samplings, growth measurements, and sample preparation. We also thank Prof. Patrice Francour of Nice University for the STATBAS software and Michael Paul for English proofreading. This study was funded in part by the Environmental Agency (ADEME) ( ${ }^{\circ}$ 0575C0004) and the PACA (Provence Alpes Côte-d'Azur) Region.

\section{References}

Abdelaziz, M., Pokluda, R., Abdelwahab, M., 2007. Influence of compost, microorganisms and NPK fertilizer upon growth, chemical composition and essential oil production of Rosmarinus officinalis. Notulae Botanicae Horti Agrobotanici Cluj-Napoca 35.

Adams, R.P., 1989. Identification of Essential Oils by Ion Trap Mass Spectroscopy Harcourt Brace Jovanovivh, San Diego, USA

Atkinson, R., Arey, J., 2003. Gas-phase tropospheric chemistry of biogenic volatile organic compounds: a review. Atmospheric Environment 37, S197-S219. 
Baquedano, F.J., Castillo, F.J., 2007. Drought tolerance in the Mediterranean species Quercus coccifera, Quercus ilex, Pinus halepensis, and Juniperus phoenicea. Photosynthetica $45,229-238$.

Bertin, N., Staudt, M., Hansen, U., Seufert, G., Ciccioli, P., Foster, P., Fugit, J.L. Torres, L., 1997. Diurnal and seasonal course of monoterpene emissions from Quercus ilex (L.) under natural conditions - applications of light and temperature algorithms. Atmospheric Environment 31, 135-144.

Blanch, J.S., Penuelas, J., Llusia, J., 2007. Sensitivity of terpene emissions to drought and fertilization in terpene-storing Pinus halepensis and non-storing Quercus ilex. Physiologia Plantarum 131, 211-225.

Boissard, C., Cao, X.L., Juan, C.Y., Hewitt, C.N., Gallagher, M., 2001. Seasonal variations in VOC emission rates from gorse (Ulex europaeus). Atmospheric Environment 35, 917-927.

Both, H., Brüggemann, W., 2009. Photosynthesis studies on European evergreen and deciduous oaks grown under Central European climate conditions. I: a case study of leaf development and seasonal variation of photosynthetic capacity in Quercus robur (L.), Q. ilex (L.) and their semideciduous hybrid, Q. $\times$ turneri (Willd.). Trees Structure and Function 23, 1081-1090.

Chapin, F.S.I., 1980. The mineral nutrition of wild plants. Annual Review of Ecology and Systematics 11, 233-260.

Constable, J.V.H., Litvak, M.E., Greenberg, J.P., Monson, R.K., 1999. Monoterpene emission from coniferous trees in response to elevated $\mathrm{CO} 2$ concentration and climate warming. Global Change Biology 5, 255-267.

Epstein, E., Keane, D.B., Meisinger, J.J., Legg, J.O., 1978. Mineralization of nitrogen from sewage sludge and sludge compost. Journal of Environmental Quality 7, 217-221.

European Environment Agency, 2009. Air pollution by ozone across Europe during summer 2008. Overview of exceedances of EC ozone threshold values for April-September 2008. EEA Technical report No 2, Copenhagen K.

Fares, S., Brilli, F., Nogues, I., Velikova, V., Tsonev, T., Dagli, S., Loreto, F., 2008 Isoprene emission and primary metabolism in Phragmites australis grown under different phosphorus levels. Plant Biology 10, 38-43.

Fischbach, R.J., Staudt, M., Zimmer, I., Rambal, S., Schnitzler, J.P., 2002. Seasona pattern of monoterpene synthase activities in leaves of the evergreen tree Quercus ilex. Physiologia Plantarum 114, 354-360.

Fuentes, J.D., Wang, D., 1999. On the seasonality of isoprene emissions from a mixed temperate forest. Ecological Applications 9, 1118-1131.

Gallardo-Lara, F., Nogales, R., 1987. Effect of the application of town refuse compost on the soil-plant system: a review. Biological Wastes 19, 35-62.

Guenther, A., 2002. The contribution of reactive carbon emissions from vegetation to the carbon balance of terrestrial ecosystems. Chemosphere 49, 837-844.

Guenther, A., Hewitt, C.N., Erickson, D., Fall, R., Geron, C., Graedel, T., Harley, P., Klinger, L., Lerdau, M., Mckay, W.A., Pierce, T., Scholes, B., Steinbrecher, R., Tallamraju, R., Taylor, J., Zimmerman, P., 1995. A global-model of natural volatile organic-compound emissions. Journal of Geophysical Research-Atmospheres 100, 8873-8892.

Guenther, A.B., Zimmerman, P.R., Harley, P.C., Monson, R.K., Fall, R., 1993. Isoprene and monoterpene emission rate variability - model evaluations and sensitivity analyses. Journal of Geophysical Research-Atmospheres 98, 12609-12617.

Hansen, U., Seufert, G., 1996. The terpenoid emission pattern of Quercus coccifera L. coincides with the emission pattern found with Quercus ilex L. In: Borrell, P.M. Borrel, P., Cvitas, T., Kelly, K., Seiler, W. (Eds.), The Proceedings of EUROTRAC Symposium 1996. Computational Mechanics Publications, Southhampton, pp. 235-239.

Harley, P.C., Litvak, M.E., Sharkey, T.D., Monson, R.K., 1994. Isoprene emission from velvet bean leaves. Plant Physiology 105, 279-285.

Hussein, M.S., Ei-Sherbeny, S.E., Khalil, M.Y., Naguib, N.Y., Aly, S.M., 2006. Growth characters and chemical constituents of Dracocephalum moldavica L. plants in relation to compost fertilizer and planting distance. Scientia Horticulturae 108 $322-331$

Ismail, C., 2005. The role of potassium in alleviating detrimental effects of abiotic stresses in plants. Journal of Plant Nutrition and Soil Science 168, 521-530.

Konstantinidis, P., Tsiourlis, G., Galatsidas, S., 2005. Effects of wildfire season on the resprouting of kermes oak (Quercus coccifera L.). Forest Ecology and Management 208, 15-27.

Krause, G.H., Weis, E., 1991. Chlorophyll fluorescence and photosynthesis: the basics Annual Review of Plant Physiology and Plant Molecular Biology 42, 313-349.

Larchevêque, M., Baldy, V., Montes, N., Fernandez, C., Bonin, G., Ballini, C., 2006a. Short-term effects of sewage-sludge compost on a degraded Mediterranean soil. Soil Science Society of America Journal 70, 1178-1188.

Larchevêque, M., Ballini, C., Korboulewsky, N., Montes, N., 2006b. The use of compost in afforestation of Mediterranean areas: effects on soil properties and young tree seedlings. Science of the Total Environment 369, 220-230.

Larchevêque, M., Ballini, C., Baldy, V., Korboulewsky, N., Ormeño, E., Montès, N., 2009. Restoration of a Mediterranean Postfire Shrubland: plant functional responses to organic soil amendment. Restoration Ecology, 9999.

Lavoir, A.V., Staudt, M., Schnitzler, J.P., Landais, D., Massol, F., Rocheteau, A., Rodriguez, R., Zimmer, I., Rambal, S., 2009. Drought reduced monoterpene emissions from the evergreen Mediterranean oak Quercus ilex: results from a throughfall displacement experiment. Biogeosciences 6, 1167-1180.

Lerdau, M., Matson, P., Fall, R., Monson, R., 1995. Ecological controls over Monoterpene emissions from douglas-fir (Pseudotsuga-Menziesii). Ecology 76, 2640-2647.

Litvak, M.E., Loreto, F., Harley, P.C., Sharkey, T.D., Monson, R.K., 1996. The response of isoprene emission rate and photosynthetic rate to photon flux and nitrogen supply in aspen and white oak trees. Plant Cell and Environment 19, 549-559.

Llusià, J., Peñuelas, J., 2000. Seasonal patterns of terpene content and emission from seven Mediterranean woody species in field conditions. American Journal of Botany $87,133-140$

Martinez, F., Cuevas, G., Calvo, R., Walter, I., 2003. Biowaste effects on soil and native plants in a semiarid ecosystem. Journal of Environmental Quality 32, 472-479.

Mengel, K., Kirkby, E.A., 2001. Principles of Plant Nutrition, 5th ed. Kluwer Academic Publishers, Dordrecht.

Navas, A., Machín, J., Navas, B., 1999. Use of biosolids to restore the natural vegetation cover on degraded soils in the badlands of Zaragoza (NE Spain). Bioresource Technology 69, 199-205.

Niinemets, U., Hauff, K., Bertin, N., Tenhunen, J.D., Steinbrecher, R., Seufert, G., 2002. Monoterpene emissions in relation to foliar photosynthetic and structural variables in Mediterranean evergreen Quercus species. New Phytologist 153, 243-256.

Ormeño, E., Bousquet-Melou, A., Mevy, J.P., Greff, S., Robles, C., Bonin, G., Fernandez, C., 2007a. Effect of intraspecific competition and substrate type on terpene emissions from some Mediterranean plant species. Journal of Chemical Ecology 33, 277-286.

Ormeño, E., Fernandez, C., Mevy, J.P., 2007b. Plant coexistence alters terpene emission and content of Mediterranean species. Phytochemistry 68, 840-852.

Ortega, J., Helmig, D., 2008. Approaches for quantifying reactive and low-volatility biogenic organic compound emissions by vegetation enclosure techniques Part A. Chemosphere 72, 343-364.

Pengcheng, G., Xinbao, T., Yanan, T., Yingxu, C., 2008. Application of sewage sludge compost on highway embankments. Waste Management 28, 1630-1636.

Peñuelas, J., Staudt, M., 2010. BVOCs and global change. Trends in Plant Science 15 133-144.

Pilar, C.D., Gabriel, M.M., 1998. Phenological pattern of fifteen Mediterranean phanaerophytes from shape Quercus ilex communities of NE-Spain. Plant Ecology $139,103-112$

Pio, C.A., Silva, P.A., Cerqueira, M.A., Nunes, T.V., 2005. Diurnal and seasonal emissions of volatile organic compounds from cork oak (Quercus suber) trees. Atmospheric Environment 39, 1817-1827.

Possell, M., Heath, J., Nicholas Hewitt, C., Ayres, E., Kerstiens, G., 2004. Interactive effects of elevated $\mathrm{CO} 2$ and soil fertility on isoprene emissions from Quercus robur. Global Change Biology 10, 1835-1843.

Rosenstiel, T.N., Ebbets, A.L., Khatri, W.C., Fall, R., Monson, R.K., 2004. Induction of poplar leaf nitrate reductase: a test of extrachloroplastic control of isoprene emission rate. Plant Biology 6, 12-21.

Ross, J., Sombrero, C., 1991. Environmental control of essential oil production in Mediterranean plants. In: Harborne, J., Tomas-Barberan, F. (Eds.), Ecological Chemistry and Biochemistry of Plant Terpenoids. Clarendon Press, Oxford, pp. 83-94.

Sabillon, D., Cremades, L.V., 2001. Diurnal and seasonal variation of monoterpene emission rates for two typical Mediterranean species (Pinus pinea and Quercus ilex) from field measurements-relationship with temperature and PAR. Atmospheric Environment 35, 4419-4431.

Sharkey, T.D., Singsaas, E.L., Lerdau, M.T., Geron, C.D., 1999. Weather effects on isoprene emission capacity and applications in emissions algorithms. Ecological Applications 9, 1132-1137.

Simon, Luchetta, L., Torres, L., 2001. Estimating the emission of volatile organic compounds (VOC) from the French forest ecosystem. Atmospheric Environment 35 (Suppl. 1), 115-126.

Soil Survey Staff, 1999. Soil Taxonomy, second ed. USDA Natural Resources Conservation Service Agriculture Handbook, Washington.

Staudt, M., Rambal, S., Joffre, R., Kesselmeier, J., 2002. Impact of drought on seasonal monoterpene emissions from Quercus ilex in southern France. Journal of Geophysical Research 107, 722-730.

Tanu, Prakash, A., Adholeya, A., 2004. Effect of different organic manures/composts on the herbage and essential oil yield of Cymbopogon winterianus and their influence on the native AM population in a marginal alfisol. Bioresource Technology 92, 311-319.

Varinou, M., Kallos, G., Tsiligiridis, G., Sistla, G., 1999. The role of anthropogenic and biogenic emissions on tropospheric ozone formation over Greece. Physics and Chemistry of the Earth, Part C: Solar, Terrestrial \& Planetary Science 24, 507-513.

von Ende, C.N., 2001. Repeated-measures analysis. In: Scheiner, S.M., Gurevitch, J. (Eds.), Design and Analysis of Ecological Experiments, second ed. Oxford University Press, pp. 134-157. 